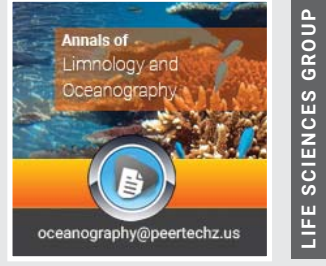

\title{
Study of Plankton diversity status of local habitat in eastern Uttar Pradesh
}

\author{
Ankita Sahu, Ram P Yadav* and Ajay Singh \\ Natural Products Laboratory, Department of Zoology, DDU, Gorakhpur University, Gorakhpur, 273009 \\ (U.P), India
}

Received: 01 September, 2021

Accepted: 30 September, 2021

Published: 01 October, 2021

*Corresponding author: Ram P Yadav, Natura Products Laboratory, Department of Zoology, DDU, Gorakhpur University, Gorakhpur, 273009 (U.P), India, E-mail: rampratapy@rediffmail.com, rampratapy123@ gmail.com

Keywords: Zooplankton; Phytoplankton; Diatoms; Reservoir

Copyright: (c) 2021 Ankita S, et al. This is an openaccess article distributed under the terms of the Creative Commons Attribution License, which permits unrestricted use, distribution, and r eproduction in any medium, provided the original author and source are credited.

https://www.peertechzpublications.com

\section{Abstract}

The studies included the local habitat of Lake River and ponds, which are most important, share the habitat in local flora and fauna in eastern Uttar Pradesh (U.P.) India. The study was conducted to assess the mainly phytoplankton and zooplankton status of the Ramgarh lake, Maheshra tal, and Rapti river in Gorakhpur district of Uttar Pradesh, India by examining the biological parameters. The most important planktonic group encountered in the present study was cyanophyceae and Zygnematophyceae Nostocale and Desimidiale encountered as other genera which existed in the Ramgarh lake, Maheshra tal, and Rapti river water of the habitat. The study found that the members of protozoans group animal contribute 50 percent of the total zooplankton population during the year of the study period.

\section{Introduction}

Water is one of the most important and most precious of natural resources and a regular plentiful supply of clean water is essential for the survival and health of most living organisms. Freshwater ecosystem is considered as one of the most essential natural resources for all the living organisms on the earth. The freshwater ecosystem include rivers, ponds etc.

The freshwater ecosystem is considered one of the most essential natural resources for all the living organisms on the earth. The various freshwater ecosystems include rivers, ponds, lakes etc. Nowadays, the significant increase in population as a result of the amount of disposal has created a major problem for its disposal. As a result, it has increased the level of water pollution and as a result the ponds have been given euteutrophication. Among, further risks to the development of ponds under the present study are the process and the increase in a human settlement near the pond. It has deteriorated the health of those ponds owing to the discharge of untreated sewage water from the nearby settlements into them [1]. Many studies have found that phytoplankton and zooplankton can be used as indicators of water pollution [2-4].
The rate of growth and development of plankton depends on various biological as well as biological factors such as light, temperature, available nutrients, oxygen concentration, $\mathrm{pH}$, etc $[5,6]$. The phytoplanktons from the basic trophic level and are succeeded by the zooplankton as the next level [7]. The population of zooplankton is influenced by the physicochemical characteristics of the body of water and it also changes according to the changes of the variation in the seasons $[8,9]$.

The Ramgarh Lake embodies an impressive landmark for the city of Gorakhpur (eastern Uttar Pradesh, India) and has great potential for development as a center for fisheries development, recreational activities and many other beneficial purposes [10]. The maheshra tal is situated in the South-East of the Gorakhpur district of Uttar Pradesh in a rich diversity of phytoplankton and zooplankton. Rapti River is the major tributary of Ghaghara river eastern Uttar Pradesh is located in the west of Gorakhpur region.

The study was conducted to assess the water quality and phytoplankton and zooplankton status of the Ramgarh lake, Maheshra tal and Rapti river in Gorakhpur district of 
Uttar Pradesh, India by examining the physicochemical and biological parameters.

\section{Materials and methods}

\section{Study area}

Water samples of Ramgarh Lake, Rapti river and Maheshra tal were collected monthly in the mid month \pm 1 day at three sampling sites from March 2020 to June 2020. Samples from the surface and bottom layers were collected at each site using one liter water sampler bottle. All the glass wares were rinsed with $10 \% \mathrm{HCl}$, deionized water and double distilled water Figure 1.

Water analysis for various physicochemical parameters the parameters were within the following range in the study total alkalinity 43-62 ppm, pH 6.8-7.7, dissolved oxygen 6.3-7.3 $\mathrm{mg} / \mathrm{L}$, total ammonia 0.29-1.59 $\mu \mathrm{g}$ at N /I [11].

\section{Qualitative and quantitative estimation of Plankton}

The plankton samples were collected from the surface only from the same spots and at the same time when and where from the water samples were taken. Each sample was collected by filtering 50 liters of surface water through a bolting silk net made of $20 \mu \mathrm{m}$ mesh size means of a bucket of 10 liters capacity. The plankton concentrate thus obtained was immediately preserved in $5 \%$ formaldehyde solution. This sample was thoroughly mixed before further analysis. The samples were then brought to the laboratory, Department of Zoology, Deen Dayal Upadhyaya Gorakhpur University Gorakhpur for qualitative and quantitative analysis of plankton. The water samples containing the plankton were dropped on the slides and were then observed under a microscope for the assessment of plankton diversity. Identification was done up to the genus level with the help of published literature $[12,13]$ A sub sample of $1 \mathrm{ml}$ was transferred to Sedgwick-Rafter plankton counting cell for differential numerical analysis. The organisms were identified up to species wherever possible and up to genera in other cases. The quantity of each species or genus was then calculated as numbers per liter in the lake water by Welch's (1935) formula [14]:

$$
\mathrm{n}=(\mathrm{a} .1000) \mathrm{c} / \mathrm{l}
$$

Where $\mathrm{n}=$ number of plankton per liter of original water.

$\mathrm{a}=$ average number of plankton in all counts in Sedgwick Rafter Cell.

$$
\begin{aligned}
& \mathrm{C}=\text { volume of original concentration in } \mathrm{ml} . \\
& 1 \text { = volume of original water expressed in liters. }
\end{aligned}
$$

\section{Results}

In the Ramgarh lake, Maheshra tal and Rapti river have hydrophytic vegetation is quite rich and includes several macrophytes and aquatic fauna. The water level of the lake, tal and river varied significantly in different parts of the year. However, the minimum value $(40 \mathrm{~cm})$ was recorded invariably in April during the years of study. With the onset of the monsoon, a gradual rise in water level was observed till touching the maximum level in the mid-month of September.

\section{Physical parameters}

Depending upon the climatic and biological conditions of the RamgarhLake, Maheshra tal and Rapti river the water changed from light grey to deep green during different months of the year. During the rainy season i.e. August to September, it
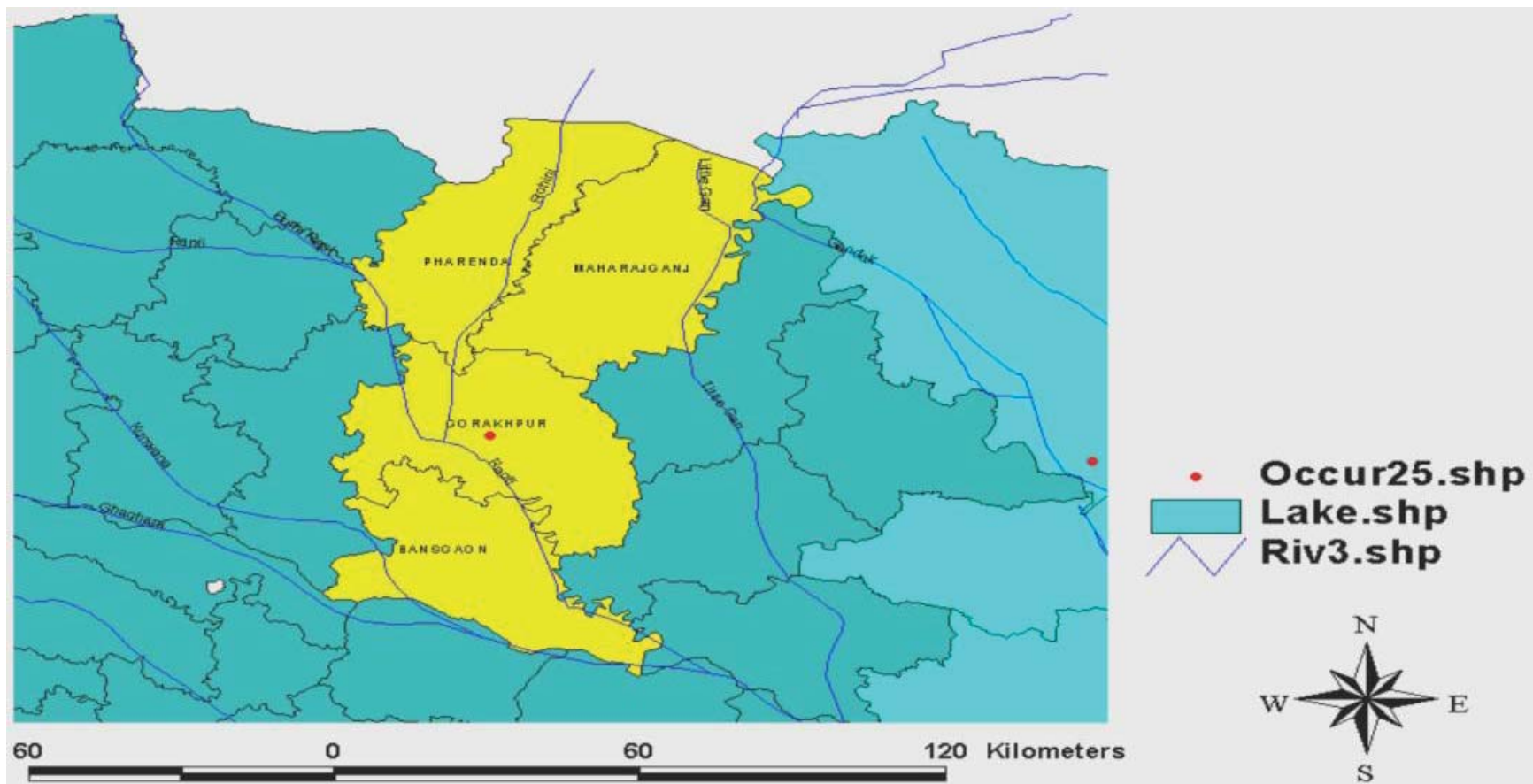

Citation: Ankita S, Ram PY, Ajay S (2021) Study of Plankton diversity status of local habitat in eastern Uttar Pradesh. Ann Limnol Oceanogr 6(1): 001-007. 
was light to deep gray, while during April to May and November to December it was deep green due to abundant growth of planktonic algae.

The temperature of the surface and bottom water was recorded every month (on15 $5^{\text {th }} 1$ day) for one year. In 2020 month of March to June, the average surface temperature during the summer season was $30^{\circ} \mathrm{C}$ and that of the bottom was $20^{\circ} \mathrm{C}$.

The lake water remained turbid during the summer and monsoon months. The transparency was low in summer (20.3 $\mathrm{cm}$ in 2020) and monsoon (19.0 cm in 2020), and did not differ much at various sampling stations.

\section{Plankton}

Phytoplankton: The member of the families Melosiraceae, Aphanizomenonaceae, Tabellariaceae, Microcystaceae, Cyanophyceae, Bracillariophyceae, Ulophyceae, Zygnematophyceae, Xanthophyceae, Volocaceae and Naviculaceae represented the phytoplankton community of Ramgarh Lake, Maheshra tal and Rapti river constituted the dominant groups of phytoplankton. A list of phytoplankton collected from the Ramgarh lake, Maheshra tal and Rapti river and their monthly occurrence has been given in the Table 1.

During the year 2020, the phytoplankton population exhibited two clear cut phases one running from March to June called the 'summer phase', while another running from July to December called post monsoon or 'winter phase'. The phytoplankton of the summer phase chiefly included members of by cyanophyceae and supported by bacillariophyceae. The members of cynophyceae made their maximum appearance from March to June. In the rest of the months either they were absent or if present they were scanty in numbers and poor in forms.

The members of families cyanophyceae, bacillariophyceae represented the phytoplankton community of Ramgarh Lake, Maheshra tal and Rapti river. Among these families Melosiraceae, Aphanizomenonaceae, Tabellariaceae, Microcystaceae, Cyanophyceae, Bracillariophyceae, Ulophyceae, Zygnematophyceae, Xanthophyceae, Volocaceae and Naviculaceae were observed predominant throughout the year and were comprised of 18 genera (Melosiraceae-01 genera, Aphanizomenonaceae-01 genera, Tabellariaceae-01 genera, Microcystaceae-02 genera, Cyanophyceae-03 genera, Bracillariophyceae-02 genera, Ulophyceae-02 genera, Zygnematophyceae-03 genera, Xanthophyceae-01 genera, Volocaceae-01 genera and Naviculaceae-01 genera), chiefly including Melosira varians, Nodularia pumigena, Asterionellopsis Formosa, Microcystis aeruginosa, Aphanizomenon flosaquae, Nostocale srivularia, Nostocales nostoc, Nostocales anabena, Naviculales pinnularia, Naviculales stauroneis, Ulotrichale sulothrix, Ulotrichales protest, Desimidiales closterium, Desimidiales desmidium, Spirogyra, Mischoccales opiocytium, Volvox and Pennales alchetron (Table 1).

The most important planktonic group encountered in the present study was cyanophyceae and Zygnematophyceae. Nostocale and Desimidiale encountered as other genera which existed in the lake, tal and river water of the habitat.
Table 1: Seasonal fluctuations in phytoplankton diversity in Ramgarh Lake, Rapti River and Maheshra tal during March 2020 to June 2020.

\begin{tabular}{|c|c|c|c|c|c|c|}
\hline $\begin{array}{l}\text { S. } \\
\text { No. }\end{array}$ & Family & Phytoplanktons & $\begin{array}{c}\text { River/lake/ } \\
\text { Tal }\end{array}$ & $\begin{array}{c}\text { Sample } \\
1 .\end{array}$ & $\begin{array}{c}\text { Sample } \\
2 .\end{array}$ & $\begin{array}{c}\text { Sample } \\
3 .\end{array}$ \\
\hline \multirow{3}{*}{1} & \multirow{3}{*}{ Melosiraceae } & \multirow{3}{*}{ Melosira varians } & Rapti & + & + & + \\
\hline & & & Ramgarh & + & + & + \\
\hline & & & Maheshra & + & + & + \\
\hline \multirow{3}{*}{2} & \multirow{3}{*}{ Aphanizomenonaceae } & \multirow{3}{*}{$\begin{array}{c}\text { Nodularias } \\
\text { pumigena }\end{array}$} & Rapti & + & + & + \\
\hline & & & Ramgarh & + & + & + \\
\hline & & & Maheshra & + & + & + \\
\hline \multirow{3}{*}{3} & \multirow{3}{*}{ Tabellariaceae } & \multirow{3}{*}{$\begin{array}{l}\text { Asterionellopsis } \\
\text { formosa }\end{array}$} & Rapti & - & - & + \\
\hline & & & Ramgarh & - & - & - \\
\hline & & & Maheshra & + & + & + \\
\hline \multirow{3}{*}{4} & \multirow{3}{*}{ Microcystaceae } & \multirow{3}{*}{$\begin{array}{l}\text { Microcystis } \\
\text { aeruginosa }\end{array}$} & Rapti & + & + & + \\
\hline & & & Ramgarh & + & + & + \\
\hline & & & Maheshra & + & + & + \\
\hline \multirow{3}{*}{5} & \multirow{3}{*}{ Cyanophyceae } & \multirow{3}{*}{$\begin{array}{c}\text { Aphanizomenon } \\
\text { flos-aquae }\end{array}$} & Rapti & - & - & - \\
\hline & & & Ramgarh & + & + & + \\
\hline & & & Maheshra & - & - & - \\
\hline \multirow{3}{*}{6} & \multirow{3}{*}{ Cyanophyceae } & \multirow{3}{*}{$\begin{array}{c}\text { Nostocale } \\
\text { srivularia }\end{array}$} & Rapti & + & + & + \\
\hline & & & Ramgarh & + & + & + \\
\hline & & & Maheshra & + & + & + \\
\hline & & & Rapti & + & + & + \\
\hline 7 & Cyanophyceae & Nostocales & Ramgarh & + & + & + \\
\hline & & & Maheshra & + & + & + \\
\hline & & & Rapti & + & + & + \\
\hline 8 & Cyanophyceae & Nostocales & Ramgarh & + & + & + \\
\hline & & & Maheshra & + & + & + \\
\hline & & & Rapti & + & + & + \\
\hline 9 & Bracillariophyceae & Naviculales & Ramgarh & + & + & + \\
\hline & & & Maheshra & + & + & + \\
\hline & & & Rapti & + & + & + \\
\hline 10 & Bracillariophyceae & $\begin{array}{l}\text { Naviculales } \\
\text { stauroneis }\end{array}$ & Ramgarh & + & + & + \\
\hline & & & Maheshra & + & + & + \\
\hline & & & Rapti & + & + & + \\
\hline 11 & Ulophyceae & Ulotrichale & Ramgarh & + & + & + \\
\hline & & & Maheshra & + & + & + \\
\hline & & & Rapti & + & + & + \\
\hline 12 & Ulophyceae & $\begin{array}{l}\text { Ulotrichales } \\
\text { protist }\end{array}$ & Ramgarh & + & + & + \\
\hline & & & Maheshra & + & + & + \\
\hline & & Desimidiales & Rapti & + & + & + \\
\hline 13 & Zygnematophyceae & closterium & Ramgarh & + & + & + \\
\hline & & & Maheshra & + & + & + \\
\hline & & & Rapti & + & + & + \\
\hline 14 & Zygnematophyceae & Desimidiales & Ramgarh & + & + & + \\
\hline & & & Maheshra & - & - & - \\
\hline & & & Rapti & + & + & + \\
\hline 15 & Zygnematophyceae & Spirogyra & Ramgarh & + & + & + \\
\hline & & & Maheshra & + & + & + \\
\hline & & & Rapti & + & + & + \\
\hline 16 & Xanthophyceae & Mischoccales & Ramgarh & + & + & + \\
\hline & & & Maheshra & + & + & + \\
\hline & & & Rapti & - & - & + \\
\hline 17 & Chlorophyceae & Volvox & Ramgarh & + & + & + \\
\hline & & & Maheshra & + & + & + \\
\hline 18 & & Pennalesal & Rapti & + & + & + \\
\hline & Bacillariophyceae & chetron & Ramgarh & - & - & - \\
\hline & & & Maheshra & + & + & + \\
\hline
\end{tabular}

$(+)$, Present (-), Absent

In Bacillariophyceae group represented by two genera i.e. Naviculate spinnularia and Naviculales stauroneis. Members of this group exhibited luxuriant growth from March to June. The data reveals that diatoms preferred to colonize during the 
warmer part of the year and they had a lean population during winter.

\section{Zooplankton}

The various groups of zooplankton recorded during the period of investigation were, (a) Protozoa (b) Nematoda (c) Ectoprocta (d) Arthropoda. Besides, insect nymphs, larvae and protozoans.

The data pertaining to the population dynamics of zooplankton and its different components like Protozoa, Nematoda, Ectoprocta and Arthropoda are given in Table 2. These data reveal that the population density of zooplankton in the Ramgarh lake, Maheshra tal and Rapti river recorded a cyclic pattern, being lowest in the rainy season, then rising through early part of winter and gradually reaching to its peak in the early part of summer in the month of April. Protozoans and aquatic insects though appeared occasionally but in negligible numbers, hence, have not been considered in the present study.

The protozoans contribute 50 percent of the total zooplankton population during the year of 2020 . The period from March to June was observed to be conducive for its growth whereas the period from June to August recorded its lean population (Table 2). Eighteen genera represented this group Amoeba verrucosa, Amoeba proteus, Amoeba vespertilio, Amoeba vulgaris, Amoeba gibbosa, Pelonyxa palustris, Diffligia muriformes, Acanthocystis, Lionotus fasciola, Nassula ornate, Glaucoma pyriformis, Monochilum ovale, Ophryoglena flava, Paramaecium Caudatum, Paradoxorhabditis paradoxus, and Arcella.

The nematode contributed 20 percent to the total zooplankton population in the year, recording their presence

Table 2: Seasonal fluctuations in Zooplankton diversity in Ramgarh Lake, Rapti River and Maheshra tal during March 2020 to June 2020.

\begin{tabular}{|c|c|c|c|c|c|c|c|}
\hline S.N. & Taxnomic group & Family & Zooplanktons & River/lake/Tal & Sample 1 & Sample 2 & Sample \\
\hline \multirow{3}{*}{1} & \multirow{3}{*}{ Protoza } & \multirow{3}{*}{ Amoebidae } & \multirow{3}{*}{ Amoeba verrucosa } & Rapti & + & + & + \\
\hline & & & & Ramgarh & + & + & + \\
\hline & & & & Maheshra & + & + & + \\
\hline \multirow{3}{*}{2} & \multirow{3}{*}{ Protoza } & \multirow{3}{*}{ Amoebidae } & \multirow{3}{*}{ Amoeba proteus } & Rapti & + & + & + \\
\hline & & & & Ramgarh & + & + & + \\
\hline & & & & Maheshra & + & + & + \\
\hline \multirow{3}{*}{3} & \multirow{3}{*}{ Protoza } & \multirow{3}{*}{ Amoebidae } & \multirow{3}{*}{ Amoeba vespertilio } & Rapti & + & + & + \\
\hline & & & & Ramgarh & + & + & + \\
\hline & & & & Maheshra & + & + & + \\
\hline \multirow{3}{*}{4} & \multirow{3}{*}{ Protoza } & \multirow{3}{*}{ Amoebidae } & \multirow{3}{*}{ Amoeba vulgaris } & Rapti & + & + & + \\
\hline & & & & Ramgarh & + & + & + \\
\hline & & & & Maheshra & + & + & + \\
\hline \multirow{3}{*}{5} & \multirow{3}{*}{ Protoza } & \multirow{3}{*}{ Amoebidae } & \multirow{3}{*}{ Amoeba gibbosa } & Rapti & + & + & + \\
\hline & & & & Ramgarh & + & + & + \\
\hline & & & & Maheshra & + & + & + \\
\hline \multirow{3}{*}{6} & \multirow{3}{*}{ Protoza } & \multirow{3}{*}{ Pelomyxidae } & \multirow{3}{*}{ Pelonyxa palustris } & Rapti & + & + & + \\
\hline & & & & Ramgarh & + & + & + \\
\hline & & & & Maheshra & - & - & + \\
\hline & & & & Rapti & + & + & + \\
\hline 7 & Protoza & Diffugiidae & Diffligia muriformes & Ramgarh & + & + & + \\
\hline & & & & Maheshra & + & + & + \\
\hline & & & & Rapti & - & - & + \\
\hline 9 & Protoza & Acanthocistidae & Acanthocystis & Ramgarh & + & + & + \\
\hline & & & & Maheshra & + & + & + \\
\hline & & & & Rapti & + & + & + \\
\hline 10 & Protoza & Fasciolidae & Lionotus fasciola & Ramgarh & - & - & - \\
\hline & & & & Maheshra & - & - & - \\
\hline & & & & Rapti & + & + & + \\
\hline 11 & Protoza & Nassulidae & Nassula ornata & Ramgarh & + & + & + \\
\hline & & & & Maheshra & + & + & + \\
\hline & & & & Rapti & + & + & + \\
\hline 12 & Protoza & Glaucomidae & Glaucoma pyriformis & Ramgarh & + & + & + \\
\hline & & & & Maheshra & + & + & + \\
\hline & & & & Rapti & + & + & + \\
\hline 13 & Protoza & & Monochilum ovale & Ramgarh & + & + & + \\
\hline & & & & Maheshra & + & + & + \\
\hline & & & & Rapti & + & + & + \\
\hline 14 & Protoza & Ophryoglenidae & Ophryoglena flava & Ramgarh & + & + & + \\
\hline & & & & Maheshra & + & + & + \\
\hline & & & & Rapti & + & + & + \\
\hline 15 & Protozoa & Parameciidae & Paramaecium Caudatum & Ramgarh & - & - & + \\
\hline & & & & Maheshra & + & + & + \\
\hline
\end{tabular}

Citation: Ankita S, Ram PY, Ajay S (2021) Study of Plankton diversity status of local habitat in eastern Uttar Pradesh. Ann Limnol Oceanogr 6(1): 001-007. 


\begin{tabular}{|c|c|c|c|c|c|c|c|}
\hline \multirow{3}{*}{16} & \multirow{3}{*}{ Protozoa } & \multirow{3}{*}{ Parameciidae } & \multirow{3}{*}{ Paradoxorhabditis Paradoxus } & Rapti & + & + & + \\
\hline & & & & Ramgarh & + & + & + \\
\hline & & & & Maheshra & + & + & + \\
\hline \multirow{3}{*}{17} & \multirow{3}{*}{ Protozoa } & \multirow{3}{*}{ Arcellidae } & \multirow{3}{*}{ Arcella } & Rapti & + & + & + \\
\hline & & & & Ramgarh & + & + & + \\
\hline & & & & Maheshra & + & + & + \\
\hline \multirow{3}{*}{18} & & & & Rapti & - & + & - \\
\hline & Nematoda & Parameciidae & Paradoxorhabditis cranganorensis & Ramgarh & + & + & + \\
\hline & & & & Maheshra & + & + & + \\
\hline & & & & Rapti & - & - & - \\
\hline 19 & Nematoda & Parameciidae & Paradoxorhabditis jodhpurensis & Ramgarh & + & + & + \\
\hline & & & & Maheshra & + & + & + \\
\hline & & & & Rapti & + & + & + \\
\hline 20 & Nematoda & Cylindrocorporidae & Gobindonema filicaudatum & Ramgarh & + & + & + \\
\hline & & & & Maheshra & + & + & + \\
\hline & & & & Rapti & + & + & + \\
\hline 21 & Nematoda & Haplolamidae & Helicotylenchus crenacauda & Ramgarh & + & + & + \\
\hline & & & & Maheshra & - & - & + \\
\hline & & & & Rapti & + & + & + \\
\hline 22 & Nematoda & Picarilaimidae & Picarilaimus caudatus & Ramgarh & + & + & + \\
\hline & & & & Maheshra & + & + & + \\
\hline & & & & Rapti & + & + & + \\
\hline 23 & Nematoda & & Albunema indicum & Ramgarh & + & + & + \\
\hline & & & & Maheshra & + & + & + \\
\hline & & & & Rapti & + & + & + \\
\hline 24 & Nematoda & & Monohystera pseudomacrura & Ramgarh & + & + & + \\
\hline & & & & Maheshra & + & + & + \\
\hline & & & & Rapti & + & + & + \\
\hline 25 & Ectoprocta & & Colony of statoblast & Ramgarh & + & + & + \\
\hline & & & & Maheshra & + & + & + \\
\hline & & & & Rapti & + & + & + \\
\hline 26 & Ectoprocta & & Statoblast & Ramgarh & + & + & + \\
\hline & & & & Maheshra & + & + & + \\
\hline & & & & Rapti & + & + & + \\
\hline 27 & Ectoprocta & & Glossiphoonia webri & Ramgarh & + & + & + \\
\hline & & & & Maheshra & + & + & + \\
\hline & & & & Rapti & + & + & + \\
\hline 28 & Ectoprocta & & Herpobdella hexaculata & Ramgarh & + & + & + \\
\hline & & & & Maheshra & + & + & + \\
\hline & & & & Rapti & + & + & + \\
\hline 29 & Arthropoda & Streptocephalidae & Streptocephalus dichotomus & Ramgarh & + & + & + \\
\hline & & & & Maheshra & + & + & + \\
\hline & & & & Rapti & + & + & + \\
\hline 30 & Arthropoda & Thamnocephalidae & Branchinella kugenumaensis & Ramgarh & + & + & + \\
\hline & & & & Maheshra & - & - & - \\
\hline & & & & Rapti & - & - & - \\
\hline 31 & Arthropoda & Triopsidae & Triops longcaudatus & Ramgarh & + & + & + \\
\hline & & & & Maheshra & - & + & + \\
\hline & & & & Rapti & - & - & - \\
\hline 32 & Arthropoda & & Eocyzius plumosus & Ramgarh & + & + & - \\
\hline & & & & Maheshra & - & - & - \\
\hline & & & & Rapti & + & + & + \\
\hline 33 & Arthropoda & Dophniiadae & Dophnia carinata & Ramgarh & + & + & + \\
\hline & & & & Maheshra & - & - & - \\
\hline & & & & Rapti & - & - & - \\
\hline 34 & Arthropoda & Dophniiadae & Dophnia lumholtzisars & Ramgarh & + & + & + \\
\hline & & & & Maheshra & - & - & + \\
\hline & & & & Rapti & + & + & + \\
\hline 35 & Arthropoda & Dophniiadae & Ceriodophina & Ramgarh & + & + & + \\
\hline & & & & Maheshra & + & + & + \\
\hline & & & & Rapti & - & - & - \\
\hline 36 & Arthropoda & Dophniiadae & Scapholebris & Ramgarh & + & + & + \\
\hline & & & & Maheshra & + & + & + \\
\hline & & & & Rapti & - & - & - \\
\hline 37 & Arthropoda & Daphniidae & Moina (female) & Ramgarh & + & + & + \\
\hline & & & & Maheshra & - & - & - \\
\hline & & & & Rapti & - & - & - \\
\hline 38 & Arthropoda & Daphniidae & Moina (Male) & Ramgarh & + & + & + \\
\hline & & & & Maheshra & - & - & - \\
\hline & & & & Rapti & - & - & - \\
\hline 39 & Arthropoda & Cyprididae & Ostracod & Ramgarh & - & - & - \\
\hline & & & & Maheshra & + & + & + \\
\hline
\end{tabular}

(+), Present (-), Absent

Citation: Ankita S, Ram PY, Ajay S (2021) Study of Plankton diversity status of local habitat in eastern Uttar Pradesh. Ann Limnol Oceanogr 6(1): 001-007. DOI: https://dx.doi.org/10.17352/alo.000010 
throughout the year. The nematode was represented by the families - Cyclindrocorporidae and haplodamidae.

The member of the phylum arthropoda belongs to the family streptocephalidae, tropsidae, arcellidae it belongs to the genera viz. Streptocephalus dichotomus, Branchinella kugenumaensis, Arcella, Eocyzius pulmosus, Triops longcaudatus.

Monitoring the physico-chemical parameters is very important for studying the influence of parameters on the distribution of various components of diversity in water. Water quality is influenced by geological, hydrological, climatic and anthropogenic factors Water temperature is considered as one of the important factors that controls aquatic life.

\section{Discussion}

Temperature plays an important role in the physical environment of the organism. It universally regulates the distribution and activities of plants and animals. According to Allen [15] and Prasad [16] temperature is a determining factor in the seasonal distribution of plankton. In the Ramgarh Lake, Maheshra tal and Rapti river plankton population was observed to flourish during the period of temperature range between $30^{\circ} \mathrm{C}$ and $28^{\circ} \mathrm{C}$

The observed dissolved oxygen content was directly correlated with the plankton population in RamgarhLake, Maheshra tal and Rapti river during the course of the study. The low level of dissolved oxygen content observed during summer months was associated with lesser number of plankton whereas increase in dissolved oxygen level was accompanied with by an increase in the plankton population. The free carbon dioxide readily dissolves in water and combines with other substances. It plays an important role in the photosynthetic activities of both terrestrial as well as aquatic plants. Pahwa and Meherotra 966) [17] and Ray, et al. [18] have observed the plankton population directly correlated with chloride concentration.

The members of cyanophyceae exhibited their maximum appearance during the summer month till the onset of the monsoon. The possible reason seems to be the availability of enough nutrients due to the increased decomposition rate. The variations of plankton population with respect to their number space and time may be due to the high rate of sewage pollution and affinity for different climatic conditions.

The taxonomy of zooplankton and their seasonal fluctuation in relation to different physico-chemical factors have been variously discussed by Michael [19], Nandy, et al. [20], Balmurugan, et al. [21,22]. The zooplankton population of Ramgarh Lake, Maheshra tal and Rapti river showed a direct correlation with dissolved oxygen. It is generally assumed that the zooplankton depends upon the phytoplankton abundance and as such the peak of the latter follows the fall of the farmer.

\section{Conclusion}

The aquatic environment is an area controlled by the changes in factors such as light, heat, humidity and contamination of various effluents in the water body. The results from this study indicated the status of plankton, followed by rich nutrients and an elevated level of zooplankton abundance in the lake, tal and river during the summer season. The study provides the role of phytoplankton and zooplanktons as bioindicators in detecting the health and trophic status of aquatic bodies. Some species withstand the extreme conditions and survive well in the polluted environment indicating high tolerance level while sensitive species were absent representing their low tolerance.

\section{Funding}

This research did not receive any specific grant from funding agencies in the public, commercial, or not-for-profit sectors.

\section{References}

1. Karmakar S (2021) Phytoplankton and Zooplankton Diversity and Water Quality Assessment of Three Ponds in Hooghly District (West Bengal,India). Research Square 1-15. Link: https://bit.ly/3CYmrg2

2. Jonnalagadda SB, Mhere G (2001) Water quality of the Odzi River in the eastern highlands of Zimbabwe. Water Res 35: 2371-2376. Link: https://bit.ly/3iloC5c

3. Ravikumar P, Venkatesharaju K, Prakash KL, Somashekar RK (2011) Geochemistry of groundwater and groundwater prospects evaluation, Anekal Taluk, Bangalore urban district, Karnataka, India. Environ Monit Assess 179: 93-112. Link: https://bit.ly/3meeU5」

4. Ajma HI, Anis AMA (2016) Zooplankton Composition and Abundance as Indicators of Eutrophication in Two Small Man-made Lakes. Trop Life Sci Res 27: 31-38. Link: https://bit.ly/3F7D9ew

5. Dhar J, Baghel RS, Sharma AK (2012) Role of instant nutrient replenishment on plankton dynamics with diffusion in a closed system: a pattern formation. Applied Mathematics and Computation 218: 8925-8936. Link: https://bit.ly/39Q2FGV

6. Elayaraj B, Selvaraju M (2015) Dynamics of micro algae in relation to water quality parameters of Pasupatheswarar Temple Pond, Annamalai Nagar, Tamil Nadu. International Letter of Natural Sciences 46: 1-7. Link: https://bit.ly/3maPMwR

7. Malik N, Biswas AK, Raju CB (2013) Plankton as an indicator of heavy metal pollution in a freshwater reservoir of Madhya Pradesh, India. Bull Environ Contam Toxicol 90: 725-729. Link: https://bit.ly/3ur9F6L

8. Hulyal SB, Kaliwal BB (2008) Water quality assessment of Almatti Reservoir of Bijapur (Karnataka State, India) with special reference to zooplankton. Environ Monit Assess 139: 299-306. Link: https://bit.ly/3mbo2bp

9. Kudari VA, Kanamadi RD (2008) Impact of changed trophic status on the zooplankton composition in six water bodies of Dharwad district, Karnataka state (South India). Environ Monit Assess 144: 301-313. Link: https://bit.ly/3mbSguX

10. Singh D, Deepak PK (2002) Water quality of Maheshra lake in Gorakhpur district. Malaysian Applied Biology 31: 27-30.

11. APHA (1998) Standard methods for the examination of water and waste. $20^{\text {th }}$ Editions. American Public Health Association, Washington D. C.

12. Needham JG, Needham PR (1972) A guide to the study of freshwater biology ( $5^{\text {th }}$ edition) Holden-Day, Inc., Sansone Street, San Francisco, C.A 105.

13. Prescott GW (1982) Algae of the Western Great Lakes area. Otto Koeltz science Publishers West Germany. Link: https://bit.ly/3ij7uxd

14. Welch PS (1935) Limnology Mc Graw Hill, N.Y. 1-471. Link: https://bit.ly/2WvmD6U

Citation: Ankita S, Ram PY, Ajay S (2021) Study of Plankton diversity status of local habitat in eastern Uttar Pradesh. Ann Limnol Oceanogr 6(1): 001-007. 
15. Allen WE (1920) A quantitative and statistical study of the plankton of the San Joaquin river and its tributaries in and near Stockton. California, 1913 Univ Calif Publ Zool 22: 1-292. Link: https://bit.ly/3zTDI8e

16. Prasad DG (1956) Further studies in the plankton of the inshore water of Mundupum. Indian Journal Fish 3: 1-42.

17. Pahwa DV, Mehrotra SN (1966) Observation on fluctuations in the abundance of plankton in relation to certain hydrological conditions of River Ganga. Proceeding National Academy Science India 34: 157-189.

18. Ray P, Singh SB, Sehgal KL (1966) A study of some aspects of the river Ganga and Yamuna at Allahabad (U.P) in 1958-59. Proc Nat Acad Sci India 36: 235272
19. Michael RG (1964) Limnological investigations on pond plankton, microfauna and chemical constituents of water and their bearing on fish production. Ph.D. thesis, University of Calcutta, Culcutta (India). Link: https://bit.ly/3D1uMzE

20. Nandy AC, Das PR, Majumdar SK (1997) Technique to obtained sustained culture of cladoceron. Daphnia lunshottzisars. Proceeding Symposia on warm water Zooplankton Special Publication. Goa 10: 540-542.

21. Balmurugan S, Gulam Mohideen BM, Subramanian P (1999) Biodiversity of zooplankton in Cauvery river stretch, Tiruchirappalli. Tamilnadu Indian Journal Aquaculture Biology 14: 21-25. Link: https://bit.ly/3D1uRTY

22. Balmurugan S, Arivazhagan R, Subramanian $P$ (2001) Seasonal variation of zooplankton population in Ayyampalayam temple tank, Tiruchirappalli, Tamilnadu, India. Journal Advanced Zoology 22: 52-55.
Discover a bigger Impact and Visibility of your article publication with

\section{Peertechz Publications}

\section{Highlights}

* Signatory publisher of ORCID

* Signatory Publisher of DORA (San Francisco Declaration on Research Assessment)

* Articles archived in worlds' renowned service providers such as Portico, CNKI, AGRIS, TDNet, Base (Bielefeld University Library), CrossRef, Scilit, J-Gate etc.

- Journals indexed in ICMJE, SHERPA/ROMEO, Google Scholar etc.

* OAI-PMH (Open Archives Initiative Protocol for Metadata Harvesting)

* Dedicated Editorial Board for every journal

* Accurate and rapid peer-review process

* Increased citations of published articles through promotions

* Reduced timeline for article publication

Submit your articles and experience a new surge in publication services (https://www.peertechz.com/submission).

Peertechz journals wishes everlasting success in your every endeavours. 